\title{
Oral Tradition of Pesantren as a Source of Studying IPS in MI / SD
}

\author{
Waluyo Satrio Adji ${ }^{1 *}$, Abdul Bashith ${ }^{2}$, Saiful Amin ${ }^{3}$, M. Imamul Mutaqin ${ }^{4}$ \\ 1,2,3,4 Universitas Islam Negeri Maulana Malik Ibrahim Malang, Indonesia \\ *Corresponding author. Email: waluyo.satrio.adji@uin-malang.ac.id
}

\begin{abstract}
The purpose of this article is to understand the oral tradition of the pesantren, planning the development of social studies learning resources for MI / SD. This research using qualitative approach with ethnographic research type, collecting data using observation, interviews, and documentation. The validity of the data was done by confirming the results of observations, interviews, documentation. Data analysis used the interactive model of Miles \& Huberman. The results showed that there are so many oral traditions in Indonesia, which are in line with learning at Madrasah Ibtidaiyah. There are oral traditions that exist in pesantren, which include mauludan, manaqiban, tahlil and talqin. Henceforth, this tradition collaborates as a development of social studies learning resources in MI / SD, especially in grade IV on primary competency point 3.3. Related to the use of oral traditions as social studies teaching materials, three things must be considered, namely: 1) its relevance to the Social Studies education curriculum, especially Basic Competencies; 2) rich in values or attitudes. Besides, the use of oral traditions as social studies teaching materials can be carried out through the three stages of the Hannafin and Peck model, namely: 1) analysis; 2) design; and 3) development and implementation.
\end{abstract}

Keywords: Pesantren Oral Traditions, Learning Resources, Social Studies MI / SD

\section{INTRODUCTION}

Social Studies according to Ahmad Susanto in his book argues that social science is the study of various social and humanities disciplines as well as necessary human activities that are scientifically packaged to provide deep insights and understanding to students, especially at the elementary and middle levels[1]

In other literature Sapriya argues that there are four objectives of social studies education as follows: 1) introducing concepts related to social life and its environment; 2) have the essential ability to think logically and critically, curiosity, inquiry, solve problems and skills in social life; 3 ) having commitment and awareness of social values; 4) can communicate, cooperate and compete at local, national and global levels.[2]

In the National Education System Law, Yulia Siska states that the main objective of social studies education at the elementary school level is to develop the ability of students to have the sensitivity to every social problem, be able to be optimistic about social issues and be trained to provide solutions to solve the social problems. [3]

However, the facts in the field have problems, IPS has failed to develop the human values of students. Social studies learning also fails to develop the social skills and other competencies needed to create a harmonious social life[4]. Susanto further explained that in the formation of the character of social care in learning, it still uses a teacher-starting approach so that evaluation is limited to the cognitive or memory or memorization domains, it can be said that learning becomes meaningless. [1]

The problem of social studies learning in schools can be drawn from a common thread that social studies learning in schools have not provided an adequate contribution to the realization of good citizenship as the 
central vision of social studies education. Therefore, it is necessary to evaluate what is the cause of not working social studies learning in schools, according to Hasan, that the material from social studies that is used as a reference for reading in schools contains facts but ignores local wisdom values. [5]

One of the efforts that can be made to treat these problems is to promote social culture in the classroom to provide meaning and benefits to students. The success of social studies learning when contextualizing social culture has been proven in several studies. It was found that students were more enthusiastic and familiar with local culture, students' interest and passion for learning had increased, teachers and books were no longer the primary learning source. [6]

The success of social studies learning when contextualizing social culture has been proven in several studies; it was found that students were more enthusiastic and familiar with local culture, students' interest and passion for learning had increased, teachers and books were no longer the primary sources of learning. [6] [7]

The diverse cultural diversity of Indonesia, which is diverse, needs sorting and selection of Indonesian culture because learning at Madrasah Ibtidaiyah is Islamic. One culture that is in line with social studies learning at MI is pesantren culture, and pesantren culture is full of cultivated and developed traditions, one of which is an oral tradition. According to Muzakka, the pesantren oral tradition is a tradition that grows and is designed in Islamic boarding schools or Muslim communities. [8]

Based on the above explanation, the development of learning media solutions is to raise the oral tradition of Islamic boarding schools in social studies learning in MI / SD. By utilizing an oral tradition which is rich in valuable content as a learning medium, social studies learning will become more meaningful. Besides, other benefits obtained include the introduction of an Islamic boarding school culture to the younger generation of Indonesia. Therefore this article focuses on the oral tradition of Islamic boarding schools as the development of social studies learning media in MI / SD.

\section{METHOD}

The approach used in this research is a qualitative approach, while the method used is the concept analysis method, which is to collect and then analyze the data in the form of the obtained concepts which are then processed into a new concept with a more interesting and fun quality. [9]In practice, this research comes from library collection materials such as books, articles, magazines, online media, research reports, and documentation sources that are in line with the object of research. Data collection techniques in this study using document techniques. Analysis techniques include identifying data, classifying data, modifying data, and interpreting or concluding.

\section{RESULT AND DISSCUSIONS}

\subsection{Pesantren Oral Traditions}

Pesantren oral traditions are all oral traditions that grow and develop in the Islamic boarding school and the santri community. This oral tradition is quite unique compared to other oral traditions because it is closely related to the learning process of Islamic teachings. Besides, the role of the Kiai or ustad is decisive in influencing the reception, response or acceptance of the centre to the tradition both in its aesthetic and pragmatic values.

The presence of the pesantren oral tradition according to Basuki in Muzakka originates from the realm of pesantren literature or pesantren literary genre, which is a Javanese literary genre, because the literary tradition of pesantren has very prominent differences compared to other Javanese literary genres. The differences with different types of literature are evident in the academic characteristics of the pesantren he puts forward, namely (1) being born and developing in the boarding school or the santri community, (2) sourced from the Koran, hadith, the sirat of the Prophet, and various stories in Islam, ( 3 ) appeared after the 1800s, (4) used the New Javanese language interspersed with Arabic, (5) used Arabic letters equipped with punctuation marks or shakals, and (6) spread through written and spoken words.

Muzakka [8] states that there are four most crucial pesantren oral traditions that depart from the written tradition. This tradition is usually closely related to life cycle ceremonies or significant events in the life of the students from birth to death. These traditions are the traditions of mauludan, manakiban, tahlilan, and talqinan. The mauludan practice is read or recited from the Prophet's maulud book (Burdah, Barzanji Natsar, Addaibai, Syaraful Anam); the tradition of manakiban is generally carried out to fulfil something hajat (circumcision, marriage, building a house, etc.) and to pay vows or nadzar. In this ritual, the santri community reads the manakib book or biographies of the guardians; generally, the biography of the king of the guardians, namely Abdul Qadir Jailani; As for talqinan and tahlilan are performed to pray for people who have died from the first day after burial until the seventh, fortieth, hundredth, year, two years, to the thousandth day. On these days the students read the tahlil and talqin books. During its development, these traditions are not only spoken at times related to the human life cycle, but these oral traditions are institutionalized collectively (jamiyah) whose implementation activities are determined by the regulations of each institution. 
Some Considerations of Oral Traditions as Social Studies Teaching Materials The oral traditions of the pesantren vary in their manifestations. Therefore, in choosing the oral tradition, it is necessary to pay attention to the principles of developing teaching materials, namely the principles of relevance, consistency, and adequacy.

As discussed above, the oral tradition has many variants, starting from folk language, folklore, traditional expressions, folk songs and others. However, in using the oral tradition as material for the development of social studies teaching materials, one must pay attention to the principles of developing teaching materials. This is done by understanding the Core and Basic Competencies that have been published by the Ministry of Education and Culture.

Social Science Subjects at the Madrasah Ibtidaiyah or elementary school level have relevant necessary competencies, namely grade IV MI / SD at point 3.4 with a description of the competence Identifying Hindu and Buddhist and Islamic kingdoms in the local area, as well as their influence on the life of the community at the time now. Meanwhile, in the basic competency column.
The research data is presented based on structure or research variables under study, namely dimensions and components.

\subsection{Dimensions of Smart Islamic University development}

Based on the data collected, it was found that the score for the compliance and alignment dimensions was 3,967 , the process and management dimension dimensions were 2,675, the technology resource availability dimension was 3,907 , the community dimension was 2,915, and the score for the output and benefit dimensions was 3,800 .

In addition to the relevance of the material aspects of the curriculum, the use of the oral tradition of Islamic boarding schools in developing social studies learning resources is also relevant to the formation of social attitudes, because oral traditions also contain moral sources in which Islamic values are derived from the AlQuran and Hadith. The following Table 1 and Table 2 is a table of social values in the pesantren oral tradition.

Table 1. Implementation Principles of Knowledge Relevance Analysis

\begin{tabular}{|c|l|l|l|}
\hline Class & \multicolumn{1}{|c|}{ Basic competencies } & \multicolumn{1}{|c|}{$\begin{array}{c}\text { Pesantren } \\
\text { Oral } \\
\text { Traditions }\end{array}$} & \multicolumn{1}{|c|}{$\begin{array}{c}\text { Subject } \\
\text { matter }\end{array}$} \\
\hline IV & $\begin{array}{l}\text { 3.4 Identifying Hindu and / or Buddhist and / or Islamic } \\
\text { kingdoms in the local area, and their influence on people's } \\
\text { lives today }\end{array}$ & $\begin{array}{l}\text { Mauludan } \\
\text { manakiban, } \\
\text { tahlilan and } \\
\text { talqinan }\end{array}$ & $\begin{array}{l}\text { Community } \\
\text { Islamic } \\
\text { Period }\end{array}$ \\
\hline
\end{tabular}

Table 2. Analysis of the Principle of Attitude Relevance

\begin{tabular}{|c|c|c|c|}
\hline Class & Competence for Social Attitudes & $\begin{array}{c}\text { Pesantren Oral } \\
\text { Traditions }\end{array}$ & Score \\
\hline \multirow[t]{3}{*}{ IV } & \multirow[t]{3}{*}{$\begin{array}{l}\text { Demonstrate honest behavior, discipline, } \\
\text { responsibility, courtesy, care, and confidence in } \\
\text { interacting with family, friends, teachers and } \\
\text { neighbors }\end{array}$} & Mauludan & $\begin{array}{l}\text { faithful and pious, } \\
\text { grateful, humble, honest, } \\
\text { friendly, fair, patient[10] }\end{array}$ \\
\hline & & manakiban, & $\begin{array}{l}\text { honest, generous, } \\
\text { patient, generous, piety } \\
\text { and people and } \\
\text { responsibility[11] }\end{array}$ \\
\hline & & Tahlilan and Talqinan & $\begin{array}{l}\text { religious values, hard } \\
\text { work, friendly / } \\
\text { communicative, social } \\
\text { care and discipline[12] }\end{array}$ \\
\hline
\end{tabular}


In addition, in the formulation of the Competence for Spiritual Attitudes, namely "Accepting, appreciating, and carrying out the teachings of the religion they adhere to". The pesantren oral tradition is contained in it because the pesantren oral tradition comes from a written tradition which is closely related to the life cycle ceremony or essential events in the life of the centre from birth to death, from mauludan, manakiban, tahlilan, and talqinan [8].

\subsection{Conceptual Model of Oral Traditions as Social Studies Teaching Materials}

There are many models in developing the pesantren oral tradition as learning material. One that can be used in creating this learning resource is the Hannafin and Peck, model. Hannafin and Peck's model is a learning design model that consists of three phases [13]. In practice, the aim of the substance of a model such as that made by Syaputra [14] but in this model in the manufacture of products there are repetition and revision stages, which can be further explained in the chart as follows.

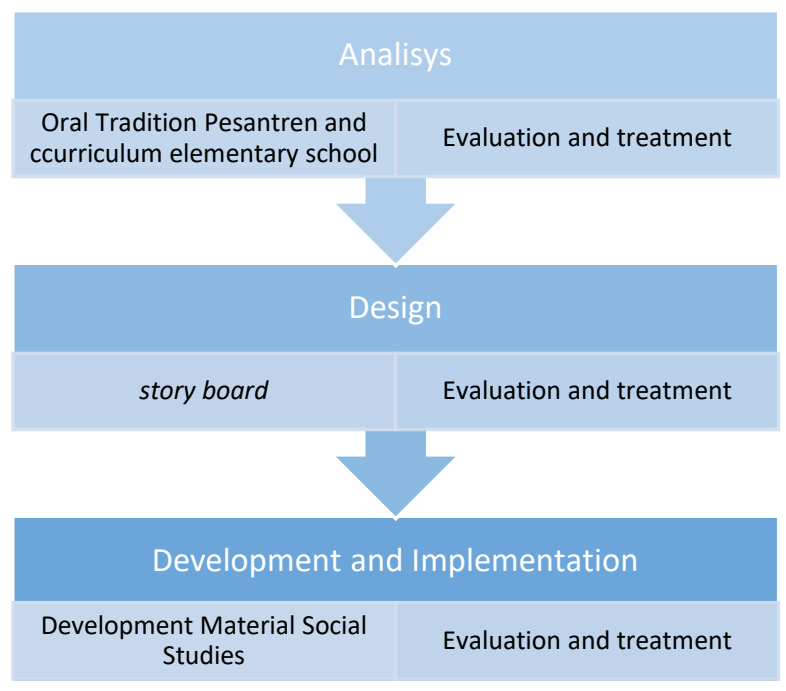

Figure 1. Conceptual Model in Developing Pesantren Oral Tradition

Based on Figure 1, there are three steps used, namely in the first phase, namely needs analysis. Pesantren oral traditions with all their wisdom must be sorted and selected by focusing on the curriculum formulated by the ministry of education and culture. If you look at the content of the curriculum at the MI / SD level, the relevance that fits this tradition is in grade IV with point 3.3. In more detail, according to Wina Sanjaya, there are seven kinds of learning needs analysis, namely 1) Stages of Gathering Information, 2) Gap Identification Stages, 3) Performance Analysis, 4) Identifying Constraints and Their Sources, 5) Student Characteristic Identification, 6) Purpose Identification, 7) Defining Problems [15].
The second phase is the design phase, at this stage, it determines what steps must be taken to make a teaching material that is made that is written briefly and clearly in a storyboard that follows the sequence of learning activities based on lesson needs. The third phase, namely the development and implementation phase, consists of generating flowcharts, testing, as well as formative and summative assessments. The storyboard document is used as a basis for developing teaching materials.

\section{CONCLUSION}

The goal of social studies learning is to form a social character that can provide solutions to various social problems which are considered unsuccessful. One of them is because the subject matter is considered less meaningful because and far from the values of local wisdom. For this reason, the development of materials based on local traditions is needed, one of which is an oral tradition with more meaningful values for social studies learning.

There are so many oral traditions in Indonesia, which are in line with learning at Madrasah Ibtidaiyah, which are the oral traditions that exist in Islamic boarding schools which include mauludan, manaqiban, tahlil and talqin. Henceforth, this tradition collaborates as a development of social studies learning resources in $\mathrm{MI} / \mathrm{SD}$, especially in grade IV on primary competency point 3.3.

Regarding the use of the oral tradition as teaching material for social studies education, three things must be considered, namely: 1) its relevance to the social studies education curriculum, especially essential competencies; 2) rich in values or attitudes; Besides, the use of oral traditions as social studies teaching materials can be carried out through the three stages of the Hannafin and Peck model, namely: 1) analysis; 2) design; and 3) development and implementation.

\section{REFERENCES}

[1] A. Susanto, Pengembangan Pembelajaran IPS di SD. Kencana, 2014.

[2] Sapriya, Pendidikan IPS Konsep dan Pembelajaran. Bandung: Remaja Rosda Karya, 2016.

[3] Y. Siska, Pembelajaran IPS di SD/MI. Garudhawaca, 2018.

[4] D. Saripudin and K. Komalasari, "Culture-based contextual social studies learning for development of social and cultural values of junior high school students," Soc. Sci., 2016, doi: 10.3923/sscience.2016.5726.5731. 
[5] S. H. Hasan, "Pendidikan Sejarah Untuk Memperkuat Pendidikan Karakter," Paramita Hist. Stud. J., 2012, doi: 10.15294/paramita.v22i1.1875.

[6] E. H. Widiastuti, "Pemanfaatan Lingkungan Sebagai Sumber Pembelajaran Mata Pelajaran Ips," Satya Widya, vol. 33, no. 1, p. 29, 2017, doi: 10.24246/j.sw.2017.v33.i1.p29-36.

[7] A. Efendi, "Implementasi Kearifan Budaya Lokal Pada Masyarakat Adat Kampung Kuta Sebagai Sumber Pembelajaran Ips," SOSIO Didakt. Soc. Sci. Educ. J., vol. 1, no. 2, Dec. 2014, doi: 10.15408/sd.v1i2.1263.

[8] M. Muzakka, "Tradisi Lisan Pesantren Dan Pemberdayaan Politik Kaum Santri (Kajian Terhadap Tradisi Shalawatan)," in http://eprints.undip.ac.id/5987/, 2010, pp. 1-8, Accessed: Sep. 10, 2020. [Online]. Available: http://bcrec.undip.ac.id/vol3/bcrec090958p 1-8.pdf.

[9] L. J. Moleong, "Metodologi Penelitian Kualitatif (Edisi Revisi)," in PT. Remaja Rosda Karya, 2017.

[10] M. Hasan, "Nilai-nilai Pendidikan Islam dalam Maulid Nabi Muhammad SAW," Al-Insyiroh J. Stud. Keislam., vol. 1, no. 1, pp. 180-213, 2015, doi: 10.35309/alinsyiroh.v1i1.3347.
[11] M. Anshori, "Nilai-Nilai Karakter Religius Didalam Manaqib Syekh Abdul Qodir Al-Jailani Karya Syekh Ja'far Al-Barzanji Dan Kontribusi Pada Pendidikan Karakter Religius Di Era Modern," Universitas Islam Negeri Maulana Malik Ibrahim Malang, 2020.

[12] M. F. Adzim, "Nilai-Nilai Pendidikan Karakter dalam Tradisi Tahlilan di Desa Sraten Kecamatan Tuntang Kabupaten Semarang. Skripsi. Jurusan Pendidikan Agama Islam. Fakultas Tarbiyah dan Ilmu Keguruan. Institut Agama Islam Negeri Salatiga. Pembimbing: Dr. Miftahuddin, M.," 2018.

[13] M. J. Hannafin and K. L. Peck, "The design, development, and evaluation of instructional software," Comput. Educ., 1988.

[14] E. Syaputra and D. Eka Citra dewi, "Tradisi lisan sebagai bahan pengembangan materi ajarPendidikan IPS di SMP: sebuah telaah literatur," J. Teor. dan Praksis Pembelajaran IPS, vol. 5, no. 1, Apr. 2020, doi: 10.17977/um022v5i12020p051.

[15] W. Sanjaya, Kurikulum Dan Pembelajaran (Teori \& Praktek KTSP). 2008. 